\title{
Desain Kurikulum Berbasis Kompetensi KKNI Pada Prodi Teknik Sipil
}

\author{
Ishak \\ Prodi Teknik Sipil Universitas Muhammadiyah Sumatera Barat \\ email : ishakumsb@gmail.com \\ DOI: http://dx.doi.org/10.31869/rtj.v3i2.1882
}

\begin{abstract}
Abstrak: Pembelajaran yang ada sekarang ini, lebih cenderung pada pembelajaran kompetitif yang lebih menekankan pada aspek kognitif semata sehingga mahasiswa mendapatkan nilai mata kuliah yang besar tetapi memiliki sifat individualistik yang tinggi, pintar hanya untuk dirinya sendiri tanpa mau berbagi mengajarkan ilmunya dengan teman-teman yang lainnya. Paradigma ini harus dirubah, menjadi pembelajaran yang kontekstual dan kolaboratif. Metode penelitian yang digunakan dalam penelitian ini adalah metode studi literatur dan pengumpulan data sekunder. Hasil dari penelitian ini adalah bahwa kurikulum berbasis kompetensi KKNI, merupakan sebuah desain kurikulum yang sangat relevan diterapkan di perguruan tinggi khususnya dalam tataran tingkat Prodi dalam rangka menyiapkan SDM yang unggul dan berdaya saing di dunia kerja. Disain kurikulum yang dibuat di Prodi teknik sipil ada tiga kategori yakni: (1) desain terpusat mata kuliah (subject centered design); (2) desain terpusat mahasiswa (learner centered design); (3) desain terpusat masalah (the problem centered designs)
\end{abstract}

Kata Kunci: kurikulum, mata kuliah, mahasiswa, masalah, kompetensi

Abstract: The existing learning today, more inclined to competitive learning that emphasizes more on the cognitive aspects only so that students get a great course value but has a high individualistic nature, smart only for himself without wanting to share teaching his knowledge with other friends. This paradigm must be changed, into contextual and collaborative learning. The research method used in this study is the method of literature study and secondary data collection. The results of this study are that the KKNI competency-based curriculum, is a curriculum design that is very relevant to be applied in tertiary institutions especially at the level of study programs in order to prepare superior and competitive human resources in the world of work. There are three categories of curriculum designs in civil engineering study programs: (1) subject centered design; (2) student centered design ; (3) the problem centered designs

Keywords: curriculum, courses, students, problem, competencies

\section{PENDAHULUAN}

Salah satu komponen penting dalam pendidikan yang sering diabaikan adalah kurikulum. Kurikulum memiliki posisi strategis karena secara umum kurikulum merupakan deskripsi dari visi, misi, dan tujuan pendidikan sebuah bangsa. Hal ini sekaligus memposisikan kurikulum sebagai sentral muatan-muatan nilai yang akan ditransformasikan kepada peserta didik. Arah dan tujuan kurikulum pendidikan akan mengalami pergeseran dan perubahan seiring dengan dinamika perubahan sosial yang disebabkan oleh berbagai faktor, baik internal maupun eksternal. Karena sifatnya yang dinamis dalam menyikapi perubahan, kurikulum mutlak harus fleksibel dan futuristik. Ketimpangan-ketimpangan dalam disain kurikulum karena kurang respon terhadap perubahan sosial boleh jadi berkonsekuensi kepada lahirnya output pendidikan yang 'gagap' dalam beradaptasi dengan kondisi sosial yang dimaksud.

Pembelajaran yang ada sekarang ini, lebih cenderung pada pembelajaran kompetitif yang lebih menekankan pada aspek kognitif semata sehingga mahasiswa mendapatkan nilai mata kuliah yang besar tetapi memiliki sifat individualistik yang tinggi, pintar hanya untuk dirinya sendiri tanpa mau berbagi mengajarkan ilmunya dengan teman-teman yang lainnya. Paradigma ini harus dirubah, menjadi pembelajaran yang kontekstual dan 
kolaboratif. Ini artinya kemampuan dosen dibutuhkan untuk mampu mengkolaborasikan secara langsung antara pemikiran dan pengetahuan dosen dengan mahasiswa maupun antara mahasiswa dengan mahasiswa yang lainnya. Dengan pola pembelajaran seperti ini, diharapkan mahasiswa tidak hanya menguasai kemampuan yang sifatnya kognitif tetapi mampu mengembangkan kecakapankecakapan lain (softskill) yang ada di dalam dirinya sendiri.

Desain kurikulum adalah sebagian dari hasil suatu pemikiran yang mendalam tentang hakikat pendidikan dan pembelajaran. (Smith dan Ragan, 2005) merinci pengertian tersebut bahwa desain merupakan proses sistemik dan reflektif dalam menerjemahkan prinsip belajar mengajar ke dalam suatu rancangan pembelajaran yang mencakup materi instruksional, kegiatan belajar, sumbersumber belajar dan sistem evaluasi. Berdasarkan beberapa definisi desain tersebut tepat jika desain kurikulum sebagai suatu bagian penting pendidikan sebab desain merupakan suatu proses perencanaan dan pengembangan kurikulum yang memuat konsep, yang bukan saja berdasarkan teori tetapi juga prinsip operasional desain sebagai pedoman pelaksanaan pendidikan untuk mencapai tujuan yang diinginkan. Artinya kita tidak mungkin bisa mengembangkan kurikulum tanpa suatu format desain yang memuat konsep dan bentuk kurikulum yang akan direkonstruksi. Konstruksi itu melibatkan analisis tujuan, konteks dan konsep desain, susunan urutan pengembangan komponen serta susunan proses implementasi dan evaluasi kurikulum. Semua komponen kurikulum dalam desain itu harus saling terkait sehingga saling keterkaitan itu meningkatkan integrasi desain sebagai satu kesatuan sistem, baik dalam proses pembelajaran maupun dalam desain instruksional untuk mencapai tujuan desain.

Salah satu dari komponen kurikulum adalah desain kurikulum, kita tidak mungkin bisa mengembangkan kurikulum tanpa suatu format desain yang memuat konsep dan bentuk kurikulum yang akan dikonstruksi.Komponen kurikulum digolongkan dalam beberapa kategori: 1 .
Desain terpusat matakuliah; 2. Desain terpusat mahasiswa dan 3. Desain terpusat masalah.

Menurut Crunkilton (1979 : 222) dalam Mulyasa, (2004 : 77) mengemukakan bahwa "kompetensi ialah sebagai penguasaan terhadap suatu tugas, keterampilan, sikap dan apresiasi yang diperlukan untuk menunjang keberhasilan". Hal tersebut menunjukkan bahwa kompetensi mencakup tugas, keterampilan, sikap dan apresiasi yang harus dimiliki oleh peserta didik untuk dapat melaksanakan tugas-tugas pembelajaran sesuai dengan jenis pekerjaan tertentu. Dengan demikian terdapat hubungan (link) antara tugas-tugas yang dipelajari peserta didik di kampus dengan kemampuan yang diperlukan oleh dunia kerja (market).

Pengembangan kurikulum di PT dimulai dari penetapan learning outcome yaitu pembelajaran yang diawali dari penentuan profil lulusan. Profil lulusan adalah gambaran suatu peran yang dapat dilakukan oleh lulusan, setelah dia berkiprah di masyarakat atau setelah mereka lulus di perguruan tinggi. Profil lulusan suatu program studi dapat berjumlah lebih dari satu, sesuai dengan analisis yang dilakukan secara eksternal terhadap lulusan melalui tracer study dan labour market signals, maupun analisis internal melalui scientific vision dan analisis SWOT program studi. Setelah profil lulusan ditetapkan, maka langkah berikutnya adalah merumuskan kompetensi yang diturunkan dari profil lulusan. Dengan menjawab pertanyaan "kemampuan apa saja yang harus dimiliki untuk menjadi profil A?". Jawaban pertanyaan inilah yang kemudian akan menjadi kompetensi lulusan. Sesuai dengan ketentuan SK Mendiknas 045/U/2002, kompetensi lulusan akan memuat atas Kompetensi Utama (penciri program studi), Kompetensi Pendukung dan lainnya (penciri institusi).

Pengembangan mata kuliah, dilakukan dengan membuat matriks hubungan antara rumusan kompetensi dengan bahan kajian (ilmu pengetahuan) yang membentuk kompetensi tersebut. Mata kuliah adalah strategi satuan pendidikan untuk mencapai kompetensi melalui berbagai model pembelajarannya. Selanjutnya, setelah mata kuliah terbentuk, barulah dihitung sks (satuan 
kredit semester) dari setiap mata kuliah yang ada. Pertimbangan menetapkan sks adalah: (1) kedalaman materi (merupakan wujud dari kompetensi mata kuliah); (2) keluasan materi (merupakan wujud dari banyak/luasnya kajian yang diperlukan); (3) strategi pembelajaran; dan (4) berbanding secara proporsional terhadap keseluruhan sks yang ditetapkan untuk program studi tersebut (misalnya S1 adalah 144 sks).

Perubahan kurikulum tidak hanya terjadi pada tataran kebijakan dan dokumen saja, namun harus diikuti dengan perubahan implementasinya. Satu prinsip utama yang berubah dalam proses pembelajaran berbasis kompetensi di perguruan tinggi adalah bahwa, capaian hasil pembelajarannya tidak lagi bertumpu pada penguasaan isi kajian dan ilmu pengetahuan, namun harus sampai bagaimana ilmu tersebut diaplikasikan dan dikembangkan di dalam peran lulusan mahasiswa setelah mereka keluar dari perguruan tinggi.

Pada kurikulum berbasis isi, mata kuliah bertujuan untuk mencapai suatu penguasaan ilmu, artinya sasaran yang akan dicapai oleh seseorang adalah ilmu pengetahuan. (Djamaludin, Abdullah Aly, 1999 : 4). Di akhir mata kuliah, mahasiswa diminta untuk menunjukkan penguasaannya akan suatu konsep tertentu. Oleh karenanya, rancangan pembelajarannya pun disusun dan ditata berdasarkan urutan logika keilmuannya. Sebetulnya, setiap satuan pendidikan memiliki sistem untuk menghasilkan lulusan yang berkualitas dengan standar yang berbeda namun walaupun berbeda, masing-masing memiliki target yang sama yaitu kesuksesan lulusannya dan mudah diserap oleh dunia kerja. Input Perguruan Tinggi (PT) adalah lulusanSMU/MA dan SMK sederajat yang mendaftarkan diri untuk berpartisipasi dalam proses pembelajaran yang telah ditawarkan. Input yang baik memiliki beberapa indikator, tidak hanya nilai kelulusan yang baik, namun terlebih penting adalah adanya sikap dan motivasi belajar yang tinggi. Setelah mendaftarkan diri dan resmi menjadi mahasiswa, tahapan selanjutnya adalah menjalani proses pembelajaran/perkuliahan. Proses pembelajaran yang baik memiliki unsur yang baik dalam beberapa hal, yaitu: (1) Organisasi PT yang sehat; (2) Pengelolaan PT yang transparan dan akuntabel;

Ketersediaan Rancangan Pembelajaran PT dalam bentuk dokumen kurikulum yang jelas dan sesuai kebutuhan pasar kerja; (4) Kemampuan dan Ketrampilan SDM akademik dan non akademik yang handal dan profesional; (5) Ketersediaan sarana-prasarana dan fasilitas belajar yang memadai. Dengan memiliki kelima unsur pembelajaran tersebut, PT akan dapat mengembangkan iklim akademik yang sehat, serta mengarah pada ketercapaian masyarakat akademik yang professional.

Pertumbuhan di sektor konstruksi yang meningkat seiring program Kementerian Pekerjaan Umum dan Perumahan Rakyat dengan dukungan anggaran yang besar untuk pembangunan jalan, bendungan, perumahan, dan berbagai macam konstruksi lainnya. Konsekuensinya, dibutuhkan pula sumber daya dukung peralatan sehingga kondisi ini meningkatkan jumlah populasi alat berat dengan berbagai merek dan jenisnya, baik di sektor industri pertambangan, konstruksi, agroindustri, dan kehutanan. Data dari Indo- analisis menunjukkan bahwa pangsa pasar alat berat berdasarkan sektor industri 2000-2016 menunjukkan: sektor kehutanan $15 \%$, konstruksi 50\%, Agroindustri $15 \%$, dan Pertambangan 20\% (IndoAnalisis.com, 2016). Di sisi lain, sumber daya manusia baik sebagai operator maupun mekanik perawatan dan perbaikan alat berat yang dibutuhkan disektor pekerjaan tersebut juga harus diperhatikan. Penyiapan SDM merupakan hal yang harus disiapkan secara khusus dengan melibatkan unsur pemerintah sebagai pengambil kebijakan, industri sebagai pengguna SDM dan pendidikan sebagai penyedia SDM.

\section{METODE PENELITIAN}

Metode penelitian yang digunakan dalam penelitian ini memiliki tahapan-tahapan, mulai dari studi literatur dan pengumpulan data sekunder. Lebih jelas dapat diuraikan dalam penjelasan dibawah ini:

1. Studi literatur

Studi literatur ini meliputi pengambilan teori-teori serta buku, jurnal ilmiah, makalah- 
makalah seminar yang berkaitan dengan penelitian ini.

2. Pengumpulan data

Pengumpulan data yaitu pengumpulan data sekunder, data sekunder adalah data yang didapat dengan mendatangi instansi terkait untuk meminta data-data sekunder yang diperlukan antara lain data kependudukan.

\section{PEMBAHASAN}

Komponen kurikulum diorganisasi dalam beberapa kategori . Secara umum hampir semua desain kurikulum diklasifikasi sebagai modifikasi atau kombinasi tiga kategori utama desain:

(1) Desain terpusat mata kuliah (subject centered design)

(2) Desain terpusat mahasiswa (learner centered design)

(3) Desain terpusat masalah (the problem centered designs)

Masing-masing kategori tersebut terdiri atas beberapa prototipe, seperti desain mata kuliah, desain disiplin ilmu dan desain bidang luas termasuk desain terpusat mata kuliah. Yang termasuk desain terpusat pada mahasiswa adalah desain kegiatan/pengalaman, desain kampus alternatif dan desain humanistik. Adapun desain terpusat pada masalah mencakup desain kehidupan, desain inti dan desain masalah sosial.

\section{Desain Terpusat Mata Kuliah}

Desain terpusat mata kuliah (subject-centered designs) merupakan desain kurikulum yang paling umum dipakai di kampus. Pada desain ini, menu pokok kurikulum adalah pengetahuan sebagai konten utama. Desain mata kuliah merupakan desain tertua dan paling populer di dunia pendidikan dan masyarakat. Hal ini disebabkan dosen dan anggota masyarakat umumnya dididik di sekolah dengan memakai desain ini.

a. Desain mata kuliah

Desain mata kuliah berasal dari sistem pendidikan Romawi yang mempengaruhi kurikulum pendidikan tinggi di Eropa sampai abad pertengahan. Ide ini yang mendasari penyokong desain ini. Artinya mahasiswa yang dibekali pengetahuan, ide dan data penting dari setiap mata kuliah yang berasal dari warisan budaya masyarakat sejak dahulu sudah dianggap siap menghadapi tantangan hidup. Apalagi dengan desain ini presentasi konten dari tiap mata kuliah lebih praktis dilakukan dalam kelas secara lisan dengan bantuan alat bantu belajar dan buku teks yang relatif mudah diakses mahasiswa dan dosen yang sebelumnya telah dilatih berdasarkan desain kurikulum mata pelajaran itu. Selain itu, desain ini mengenalkan mahasiswa pada pengetahuan esensial masyarakat yang mengandung ide-ide besar sosialisasi. Dari segi sistem instruksional, desain ini lebih fokus pada pengajaran (teaching) daripada pembelajaran (learning) berdasarkan kenyataan bahwa sistem penyampaiannya didominasi ekspose verbal materi ajar oleh dosen kepada mahasiswa.

b. Desain disiplin ilmu

Desain disiplin ilmu (the disiplines design) atau disebut kurikulum akademik muncul sampai tahun 1960an, Walau kedua desain mata kuliah dan desain disiplin sama-sama berisi pengetahuan tetapi desain mata kuliah tidak didasarkan fondasi atau orientasi keilmuan yang jelas, jika dibandingkan dengan desain disiplin yang penyusunan atau orientasi keilmuannya sangat jelas yaitu berdasarkan disiplin akademik. Menurut King dan Brownel (1966), penyokong utama desain disiplin ilmu, disiplin berarti pengetahuan spesifik yang dikembangkan sekelompok ilmuwan yang membentuk masyarakat otonom, memiliki tradisi keilmuan dan bahasa ilmiah, sistem penelitian, struktur konsepsual, jaringan komunikasi, standar evaluasi dan standar afektif sendiri.

c. Desain bidang luas

Desain bidang luas (the broad fields designs) biasa dikenal sebagai interdisciplinary design, adalah suatu variasi dari desain mata kuliah. Desain ini merupakan perubahan dari desain tradisional. Walau desain ini muncul pertamakali di tingkat pendidikan 
tinggi pada tahun 1910-an. Sebagai respons terhadap kelemahan kurikulum sebagai mata pelajaran yang terpisah-pisah itu pada kedua desain terdahulu, beberapa ahli kurikulum menyatukan beberapa mata pelajaran atau disiplin ilmu terkait menjadi satu mata bidang studi yang lebih luas. Masalah utama desain bidang luas adalah penyempitan atau pengurangan materi pelajaran atau disiplin ilmu yang digabungkan. Lebih serius lagi penggabungan mengakibatkan disintegrasi keutuhan disiplin atau mata kuliah, jika dibandingkan dengan keutuhan tiap mata kuliah dalam desain mata kuliah yang terpisah-pisah. Artinya desain bidang luas menimbulkan masalah keluasan, kedalaman dan keutuhan masing-masing mata kuliah yang digabung. Salah satu jalan keluar menghadapi masalah keluasan dan kedalaman ini dalam desain bidang luas, misalnya melalui pembelajaran yang bukan fokus pada pengajaran semua materi, tetapi lebih fokus pada pemberian kesempatan kepada mahasiswa untuk mempelajari aplikasi gabungan mata kuliah itu dalam pemecahan masalah lintas bidang studi atau disiplin ilmu.

d. Desain korelasi dan fused plan

Desain korelasi muncul jika dua disiplin ilmu direlasikan atau menggabungkan/ mengaitkan dua bidang studi untuk memperluas pengetahuan mahasiswa atau mengurangi fragmentasi konten kurikulum, sedangkan fused plan menghubungkan lebih dari dua bidang studi atau disiplin ilmu.

e. Desain kurikulum integrasi

Sejak dahulu banyak pakar yang menginginkan kurikulum terintegrasi sebagai cara untuk membuat kurikulum lebih relevan dan kurang abstrak, sehingga lebih bermakna bagi mahasiswa. Ide ini sejalan dengan prinsip pendidikan terpusat. Perlunya integrasi bukan hanya berdasarkan teori saja, tetapi juga berdasar temuan penelitian antar disiplin ilmu. Integrasi juga diperlukan untuk mengurangi beban belajar mahasiswa yang sudah padat sebagai akibat ledakan pengetahuan yang diperkuat keinginan agar pendidikan lebih berorientasi proses daripada berorientasi konten. Unit-unit mata kuliah dari beberapa bidang ilmu yang terdiri atas kegiatan berbasis tema menjadi muatan pokok desain kurikulum terintegrasi, daripada desain yang hanya memuat unit-unit konten beberapa mata kuliah. Karakteristik desain integrasi termasuk pemberian kesempatan belajar kepada mahasiswa agar aktif melakukan eksplorasi , interpretasi, keterlibatan dan kerjasama daripada lebih fokus pada pengajaran konten saja. Kekuatan desain integrasi terletak pada pemberian kesempatan belajar (learning activities) untuk mengembangkan kemampuan nalar tingkat tinggi dan kedalaman analisis (high order of cognitive with analysis), sehingga mahasiswa dapat membedakan antara fakta dan opini, antara informasi yang akurat dan tidak akurat, antara fantasi dan realita. Selain itu dalam pemecahan masalah mahasiswa difasilitas mengembangkan kreativitas untuk menemukan pemikiran baru, unik dan original yang berkontribusi bagi pengembangan berpikir konsepsual dan berpikir intregratif.

f. Desain proses

Desain proses lebih perhatian pada upaya memfasilitasi mahasiswa agar mampu memahami dan melakukan proses atau prosedur bagaimana pengetahuan diperoleh. Desain proses mensyaratkan juga pengajaran kecerdasan dan pengembangan karakter intelektual yang diperlukan seseorang untuk berpikir efektif dan produktif. Karakter intelektual menjangkau lebih jauh daripada pemakaian dan kecepatan kemampuan intelek serta kemampuan mengingat kembali informasi rinci saja. Adapun karakter intelektual mencakup seperangkat disposisi yang 
membentuk dan mengaktifkan tingkah laku intelektual. Menurut desain proses postmodern, mahasiswa belajar proses perolehan pengetahuan. Kurikulum yang sesuai dengan ide ini tentu kurikulum yang mengajarkan metode bagaimana memproses pemahaman tentang cara menggenerasi pengetahuan (knowledge generation) atau mengkonstruksi pengetahuan (knowledge construction), bukan hanya sekedar mengajar mahasiswa memperoleh pengetahuan jadi dalam buku teks melalui pengajaran dosen di kelas. Desain proses di era postmodern mengutamakan penguasaan bahasa yang diperlukan mahasiswa agar dapat mengkonstruksi dan mempresentasikan realita. Desain proses bisa menjadi desain kurikulum yang paling dinamis di masa depan, dan malahan makin lama makin berkembang manjadi bagian terpenting dari kurikulum terpusat.

\section{Desain Terpusat Mahasiswa}

Desain terpusat mahsiswa (learner-centered designs) fokus pada perkembangan mahasiswa. Desain ini muncul sebagai respons terhadap keinginan agar pendidikan fokus pada mahasiswa dari pada mata kuliah. Karena itu kurikulum perlu didesain dengan mempertimbangkan kebutuhan, bakat, dan minat mahasiswa. Desain ini tidak direncanakan terlebih dahulu tetapi disusun oleh dosen dan mahasiswa. Karena desain ini mengutamakan mahasiswa, mata kuliah dan konten digantikan mahasiswa dengan variasi desain sebagai berikut:

a. Desain terpusat pengalaman

Berasal dari teori (Rousseau, 1762, 1911) tentang kebutuhan anak atas banyak diskripsi dan ketrampilan sehingga pendidik perlu memberikan kesempatan kepada anak mengobservasi alam agar anak belajar dari alam. Prinsip pembelajaran ini sesuai filsapat pragmatisme yang menempatkan anak sebagai pusat atau aktor pembelajaran, artinya untuk memaksimalkan pembelajaran tiap individu siswa harus terlibat aktif dalam setiap proses pembelajaran yang mereka ikuti. Kadar keterlibatan mahasiswa bervariasi, antara suatu konteks atau mahasiswa dengan konteks atau mahasiswa lainnya. Asumsi yang mendasari desain ini adalah jika siswa harus mempelajari sesuatu dia harus mempelajarinya sendiri.

b. Desain kampus alternatif

Esensi pendidikan baru adalah kebebasan mahasiswa melalui maksimalisasi kebebasan pengembangan individu sehingga bisa mengembangkan diri sesuai kebutuhan dan keinginannya. Seorang mahasiswa memiliki potensi untuk bertindak bijaksana dan realistis tanpa campur tangan orang dewasa dia akan berkembang sejauh mereka dapat berkembang. Kelas terbuka menjadi kelas alternatif yang memberikan kebebasan kepada mahasiswa melakukan eksplorasi bidang studi akademik dengan dosen berperan sebagai narasumber. Jenis sekolah ini menghasilkan banyak tipe kampus alternatif berupa "campus without walls" yang menumbuhkan gagasan kota sebagai ruang belajar.

c. Desain humanistik

Sasaran desain ini adalah menyediakan lingkungan belajar yang kondusif bagi mahasiswa agar berkembang menjadi a fully functioning person (manusia seutuhnya). Pembelajaran yang bermakna harus merupakan self initiated, inisiatif mahasiswa sendiri. Walaupun dorongan belajar berasal dari luar mahasiswa, keinginan melakukan penemuan dan motivasi untuk belajar perlu dikembangkan agar dari dalam diri mahasiswa itu sendiri (inner directed) yang dimungkinkan oleh fitrah manusia untuk merealisasikan kemampuan, kesejahteraan, dan perkembangan diri.

\section{Desain Terpusat Masalah}

a. Desain situasi kehidupan

Berdasarkan bahwa mahasiswa dapat memperoleh pembelajaran yang lebih 
bermakna jika yang dipelajarinya itu mirip dengan permasalahan yang ada di masyarakat. Kekuatan desain ini terletak pada konten kurikulum yang terkait pemecahan masalah nyata kehidupan sehingga berkontribusi pada pengalaman bermakna bagi mahasiswa. Kelemahan desain ini mirip dengan kelemahan desain terpusat pada mahasiswa, yitu kelangkaan akan dosen profesional sebab desain ini berbeda dengan desain konvensional. Selain itu tidak tersedia peralatan dan buku teks di pasaran.

b. Desain inti

Kurikulum inti didesain untuk menyediakan pendidikan umum bagi semua mahasiswa terkait masalah kehidupan manusia umumnya. Karena itu kurikulum inti mencakup konsep, ketrampilan dan sikap yang diperlukan semua orang untuk dapat berfungsi efektif di masyarakat. Ada beberapa variasi desain inti. Inti mata kuliah (subject matter core), misalnya bisa diklasifikasi sebagai desain mata kuliah dan desain inti situasi kehidupan (areas of living core). Kekuatan utama desain ini adalah unifikasi konten dari beberapa mata kuliah atau disiplin ilmu terbaru yang relevan dengan mahasiswa. Hal ini mengembangkan kemampuan siswa memproses informasi sehingga secara aktif meningkatkan motivasi intrinsik mahasiswa agar terlibat dalam kegiatan pembelajaran. Kekuatan lain desain ini berkaitan dengan konten yang bertumpu pada pengalaman atau keinginan mahasiswa sendiri. Dengan fokus pada pengalaman yang akrab dengan masalah yang dihadapi mahasiswa di masyarakat, desain ini mengembangkan kemampuan pemecahan masalah nyata di masyarakat. Apalagi pengalaman tersebut muncul dari mata kuliah yang dipelajari mahasiswa secara terintegrasi yang hasilnya dapat diaplikasi untuk memecahkan masalah personal dan sosial dari mahasiswa. Ini berarti desain inti membangun relevansi antara yang dipelajari di kampus dan kehidupan nyata mahasiswa.

c. Desain masalah sosial dan rekonstruksionis

Beberapa pendidik percaya kurikulum bisa membantu perbaikan kehidupan sosial masyarakat untuk mencapai kehidupan masa depan yang adil. Penyokong desain kurikulum rekonstruksi sosial menginginkan agar kurikulum berfungsi sebagai instrumen untuk mengembangkan kemampuan mahasiswa melakukan rekonstruksi sosial bagi kehidupan masyarakat yang lebih baik. Sasarannya adalah relevansi kurikulum dengan kebutuhan masyarakat sehingga kehidupan demokrasi bermanfaat bagi semua warga negara, bukan hanya bagi kebaikan kehidupan masyarakat tertentu saja.

\section{PENUTUP \\ Simpulan}

Berdasarkan dari studi literatur yang ada dapat disimpulkan, pengkategorian desain kurikulum sebagai berikut:

1. Kurikulum Berbasis Kompetensi KKNI, merupakan sebuah desain kurikulum yang sangat relevan diterapkan di perguruan tinggi khususnya dalam tataran tingkat Prodi dalam rangka menyiapkan SDM yang unggul dan berdaya saing di dunia kerja. Selanjutnya, agar kurikulum berbasis kompetensi di perguruan tinggi dapat terlaksana dengan optimal, dibutuhkan evaluasi kurikulum terhadap desain kurikulum yang dibuat.

2. Disain kurikulum yang dibuat di Prodi teknik sipil ada tiga kategori yakni: (1) Desain terpusat mata kuliah (subject centered design); (2) Desain terpusat mahasiswa (learner centered design); (3) Desain terpusat masalah (the problem centered designs)

\section{Saran}

Beberapa hal yang dapat disarankan guna memperbaiki dan menyempurnakan penelitian ini sebagai berikut: 
1. Untuk mengatasi setiap permasalahan yang muncul dalam pembuatan desain kurikulum, maka sangat dituntut kearifan pihak kampus dalam hal ini Prodi untuk selalu melibatkan dosen, BPH, Stakeholders dan semua pihak yang terlibat dalam melakukan pengelolaan kurikulum di Prodi.

2. Dalam pelaksanaan kurikulum berbasis kompetensi diperlukan juga kerjasama dengan instansi terkait dan asosiasi dalam melaksanakan pelatihan dan penerbitan sertifikat keahlian/ketrampilan yang pelaksanaannya di kampus dan dengan biaya yang terjangkau oleh mahasiswa.

\section{DAFTAR PUSTAKA}

Ansyar Mohamad (2015). Kurikulum: Hakikat, Fondasi, Desain dan Pengembangan, Kencana Prenadamedia Group, Jakarta.

Ditjen - Dikti. 2009. Kurikukum Berbasis

Kompetensi (KBK)

Konsep Pengembangan Kurikulum Berbasis Kompetensi di Pendidikan Tinggi.

Gufron, Anik 2004. Urgensi Kurikulum Berbasis Kompetensi bagi Lembaga 2013. Jurnal Lektur Vol. X Edisi Januari-Juni. Cirebon: STAIN Press.

Keputusan Menteri Pendidikan Nasional Republik Indonesia Nomor 234/U/2000 Tentang Pedoman Pendirian Perguruan Tinggi.

Keputusan Menteri Pendidikan Nasional Republik Indonesia Nomor 045/U/2002 Tentang Kurikulum Pendidikan Tinggi.

Mulyasa, E. 2006. Implementasi Kurikulum 2004 : Panduan Pembelajaran KBK. Bandung : Remaja Rosda Karya. 2002. Kurikulum Berbasis Kompetensi, Konsep, Karakteristik dan Implementai. Bandung : Remaja Rosda Karya.

Purnomo, Heri. 2013. Implementasi Kurikulum 2013 Cirebon: Radar, 22 Maret

M. Thaib Razali, Siswanto Irman. 2015. Inovasi Kurikulum Dalam Pengembangan Pendidikan. Jurnal Edukasi Volume 1 No. 2 